\title{
Study on Frost Heave Evaluation System of Large Canal Foundation Soil in Cold Area
}

\author{
Dong-He Ma ${ }^{1,2 *}$, Chun Tan ${ }^{1,2}$, Ye-Ting Wang ${ }^{3}$, Ta-Na He${ }^{3}$, and Yan-Long Wang ${ }^{1,2}$ \\ ${ }^{1}$ China Water Northeastern Investigation, Design \& Research Co., Ltd., Changchun, Jilin, 130000, China \\ ${ }^{2}$ Research Center on Cold Region Engineering Ministry of Water Resources, Changchun, Jilin, 130000, China \\ ${ }^{3}$ State Grid Xinyuan Holding Co., Ltd, Beijing, 100761, China
}

\begin{abstract}
Frost heave of canal foundation soil is the main factor of destroying canal system engineering in the cold area. Restricted by technical and economic conditions, further evaluation of the frost heaving index and system of the large channel in cold areas where needed. Based on the field investigation and relevant evaluation methods, several evaluation indexes such as water content, compaction coefficient, fine grain content, and cumulative negative surface gas temperature, the direction of canal slope are selected. Combined with the observation results of the prototype test field for many years, the frost heave degree of large channel foundation soil was comprehensively evaluated. The purpose of this paper is to standardize the evaluation method of frost heave characteristics of canal foundation soil in cold region, which has important guiding significance for the prevention and control of road frost damage in the cold region.
\end{abstract}

\section{Introduction}

The frost heave degree of large channel foundation soil in cold areas is influenced by the water content, compaction coefficient, fine grain content, cumulative negative surface gas temperature, the direction of canal slope, and many other factors [1-5]. When carrying out the prevention and control work of canal frost damage according to the influence factors of frost heave, in addition to carrying out necessary investigation and monitoring of canal frost heave in a cold area, the possibility of frost heaving of canal foundation soil should be studied in advance. With the development of related subjects and the deepening of problem cognition, many evaluation techniques have been formed in the field of engineering, including fuzzy analysis, operation analysis, artificial neural network, etc.

Large channel project in the cold area of northern China, the project line is long, the climate and geological conditions along the line are different. Therefore, the frost heave degree of foundation soil in different channel sections is different, and the measures to deal with the frost damage are different for different frost heaving conditions. To evaluate the frost heave degree of the canal foundation soil, to grade the quantity of frost heaving, and to implement different measures by sections is helpful for the management to optimize the resources and improve the efficiency of frost damage treatment. It is the concrete embodiment of improving the scientific management level of engineering and is also the objective need for the development of related subjects and technologies.

\section{Evaluation index}

The determination of evaluation standards is not only related to the characteristics of indexes but also closely related to the requirements of evaluation methods. By the principle of easy access to the indexes, and try to make every index in the system can be described quantitatively, there is a need to understand the range of changes in each index so that the quantification of the indicators can be achieved. For the index grade division, refer to the "Code for design of hydraulic structures against ice and freezing action" (GB/T50662), the soil frost heaving grade is divided into 5 grades (Table 1). According to the longterm practice and a large number of research conclusions, the water content, compaction coefficient, fine grain content, the cumulative negative surface gas temperature, and the direction of canal slope are selected as five indexes. These indexes are divided into five levels according to the standard values by five influence descriptions: "very weak", "weaker", "stronger", "strong" and "very strong".

Table 1. Level of frost heaving of soil

\begin{tabular}{cccccc}
\hline $\begin{array}{c}\text { Level of } \\
\text { frost } \\
\text { heaving of } \\
\text { soil }\end{array}$ & $\begin{array}{c}\text { No- } \\
\text { frost } \\
\text { heaving }\end{array}$ & $\begin{array}{c}\text { Weak } \\
\text { hrost }\end{array}$ & $\begin{array}{c}\text { Frost } \\
\text { heaving }\end{array}$ & $\begin{array}{c}\text { Strong } \\
\text { frost } \\
\text { heaving }\end{array}$ & $\begin{array}{c}\text { Extra- } \\
\text { heavy } \\
\text { frost } \\
\text { heaving }\end{array}$ \\
\hline $\begin{array}{c}\text { GB/T50662 } \\
\text { Frostheaving } \\
\text { quantity } \\
h(\mathrm{~cm})\end{array}$ & $h \leq 2$ & $2<h \leq 5$ & $5<h \leq 12$ & $12<h \leq 22$ & $h<22$ \\
\hline
\end{tabular}




\begin{tabular}{|c|c|c|c|c|}
\hline $\begin{array}{l}\text { Evaluation } \\
\text { target of } \\
\text { frost } \\
\text { heaving }\end{array}$ & $\begin{array}{l}\text { Very } \\
\text { weak }\end{array}$ & Weaker Stronger & Strong & $\begin{array}{c}\text { Very } \\
\text { strong }\end{array}$ \\
\hline
\end{tabular}

\subsection{Water content}

The influence index of the water content of large canal foundation soil mainly includes the minimum distance between the groundwater level and the frozen surface during freezing, according to the classification of the level of frost heaving in G.0.1 Appendix G of GB50007, the index can be divided into 5 grades.

\subsection{Compaction coefficient}

The results show that the frost heaving rate increases with the increase of compaction coefficient under the same conditions. The evaluation grade of the compaction coefficient is shown in Table 2.

Table 2 Evaluation grade of compaction coefficient

\begin{tabular}{lccccc}
\hline $\begin{array}{c}\text { Evaluation } \\
\text { grade }\end{array}$ & I & II & III & IV & V \\
\hline $\begin{array}{l}\text { Compaction } \\
\text { coefficient }\end{array}$ & $>0.99$ & $0.99 \sim 0.97$ & $0.97 \sim 0.94$ & $0.94 \sim 0.91 \leq 0.91$ \\
\hline
\end{tabular}

\subsection{Compaction coefficient}

For the influence of fine grain content, it is generally considered that the soil with the content $\leq 0.075 \mathrm{~mm}$ and less than $10 \%$ is no-frost heaving soil, and the frost heaving rate increases with the increase of fine grain content, but decreases when the fine grain content exceeds a certain proportion. According to the quality ratio of the fine grain content less than $0.075 \mathrm{~mm}$ in the canal foundation soil, the standard value interval is divided, and the evaluation grade of the fine grain content index accords with the stipulation of Table 3 .

Table 3 Evaluation grade of fine grain content

\begin{tabular}{cccccc}
\hline $\begin{array}{c}\text { Evaluation } \\
\text { grade }\end{array}$ & I & II & III & IV & V \\
\hline $\begin{array}{c}\text { Fine grain } \\
\text { content } \\
\begin{array}{c}\text { Particle } \\
\text { size }<0.075 \mathrm{~mm})\end{array}\end{array}$ & $<5$ or $>60$ & $\begin{array}{c}5 \sim 10 \text { or } \\
40 \sim 60\end{array}$ & $10 \sim 15$ & $15 \sim 30$ & $30 \sim 40$ \\
\hline
\end{tabular}

\subsection{Cumulative negative surface gas temperature}

For the interval setting of the cumulative negative surface gas temperature, according to the observation data of many years, when the cumulative negative surface gas temperature is $-40^{\circ} \mathrm{C}$ or lower, the depth of freezing and the thickness of freezing are close to or reach the maximum value when the impact on the canal is the most serious; The initial temperature of an average month is more than $-5^{\circ} \mathrm{C}$ when the frost depth and frost heaving amount are small. Besides, according to the basic characteristics of the monthly average negative temperature, the cumulative negative surface gas temperature decreases linearly from $-5^{\circ} \mathrm{C}$ to $-40^{\circ} \mathrm{C}$, as shown in Fig 1, the temperature range is divided into three intervals. The evaluation grades of the cumulative negative surface gas temperature are shown in Table 4.

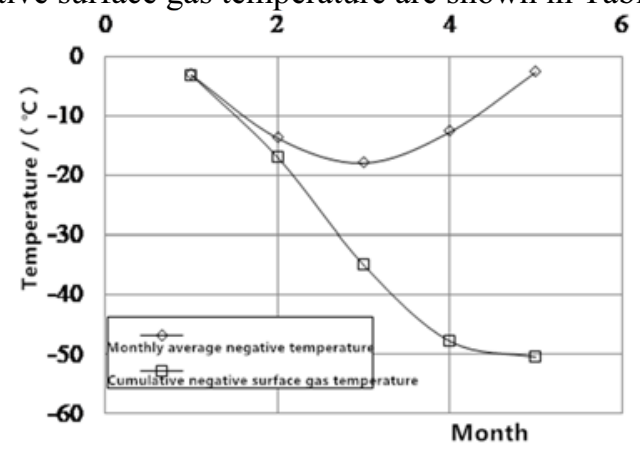

Fig.1 Basic characteristics of the monthly average negative temperature

Table 4 Evaluation grade of cumulative negative surface gas temperature

\begin{tabular}{ccccccc}
\hline Evaluation grade & I & II & III & IV & V \\
\hline $\begin{array}{c}\text { Cumulative negative } \\
\text { surface gas temperature }\end{array}$ & $>-5.0$ & $-5 \sim-17$ & $-17 \sim-29$ & $-29 \sim-40$ & $<-40$ \\
\hline
\end{tabular}

\subsection{The direction of canal slope}

The direction of large canal slope is shown in Fig.2. According to the observation results of in-situ frost heave test of large canal, the frost depth or the quantity of frost heaving of large canal shady slope is greater than that of sunny slope, and the ratio is 1.3 or even greater. According to this, the evaluation grade of the direction index of canal slope is given in Table 5 .

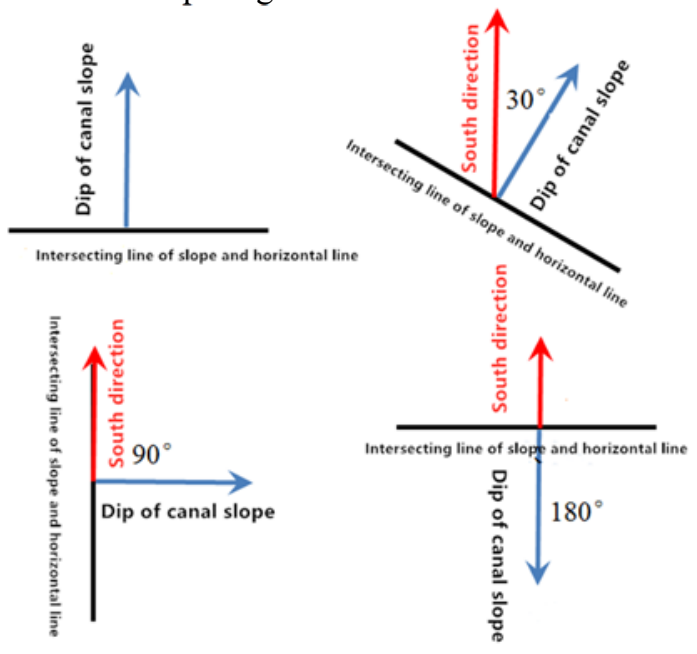

Fig.2 Schematic diagram of the direction of large canal slope

Table 5 Evaluation grade of the direction of canal slope

\begin{tabular}{ccccccc}
\hline Evaluation grade & I & II & III & IV & V \\
\hline $\begin{array}{c}\text { The direction of } \\
\text { canal } \\
\text { slopeIntersection }\end{array}$ & $0 \sim 36$ & $36 \sim 72$ & $72 \sim 108$ & $108 \sim 144$ & $144 \sim 180$ \\
\hline
\end{tabular}


angle of dip of slope

and south direction

$\left({ }^{\circ}\right)$

\section{Evaluation system and evaluation procedure}

By using analytic hierarchy process (AHP), the frost heave evaluation system of large canal in cold area is established, which is composed of target layer A, criterion layer B and index layer $C$. The characteristics of canal foundation soil in the criterion layer B1 include three index layer parameters: water content, compaction coefficient and fine grain content, and the characteristics of the external environment in the criterion layer B2 include two index layer parameters: cumulative negative surface gas temperature and the direction of canal slope. The frost heave evaluation system of foundation soil is shown in Table 6.

Table 6 Evaluation index system of the level of frost heaving

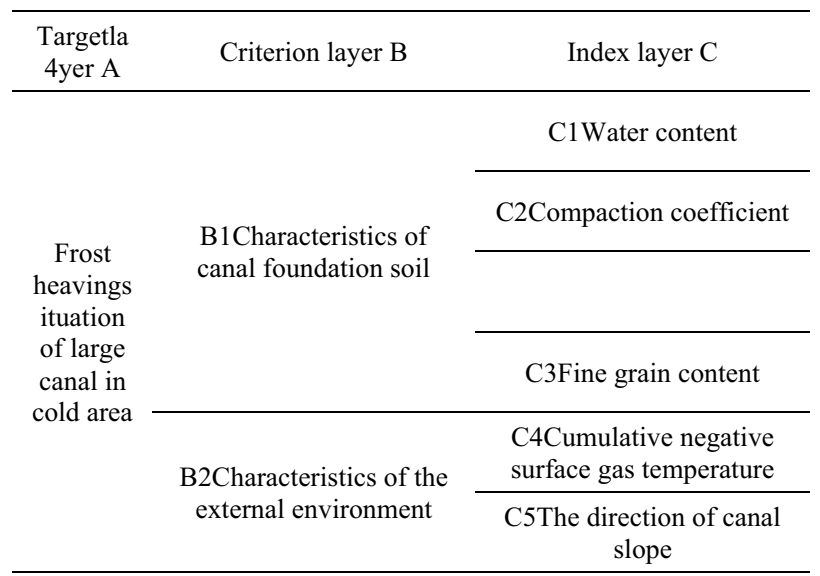

The pre-determined objective of frost heave evaluation of foundation soil is described as "very weak", "weaker", "stronger", "strong", and "very strong", which correspond to five evaluation grades of Grade I, II, III, IV and $\mathrm{V}$ respectively (Table 1 ).

\section{Application of evaluation system}

\subsection{Weight of each parameter in index layer}

The weighting factors for each parameter are determined as shown in Table 7:

Table 7 Weight score of each parameter

\begin{tabular}{|c|c|c|c|}
\hline \multicolumn{2}{|c|}{ Weight of criterion layer } & \multicolumn{2}{|c|}{ Weight of index layer } \\
\hline \multirow{3}{*}{$\begin{array}{l}\text { B1 Characteristics } \\
\text { of canal foundation } \\
\text { soil }\end{array}$} & \multirow{3}{*}{0.53} & C1 Water content & 0.29 \\
\hline & & $\begin{array}{l}\text { C2 Compaction } \\
\text { coefficient }\end{array}$ & 0.15 \\
\hline & & C3 Fine grain content & 0.26 \\
\hline & 0.47 & $\begin{array}{l}\text { C4 Cumulative negative } \\
\text { surface gas temperature }\end{array}$ & 0.21 \\
\hline
\end{tabular}

\begin{tabular}{ccc}
\hline $\begin{array}{c}\text { B2 Characteristics } \\
\text { of the external } \\
\text { environment }\end{array}$ & C5 The direction of canal \\
slope & 0.09
\end{tabular}

The subordinate scores of each index are determined according to "technical code for monitoring canal safety of cold area", and the comprehensive scores of frost heave of foundation soil are calculated according to the formula (1):

Table 8 Subordinate scores of each index

\begin{tabular}{ccccccc}
\hline $\begin{array}{c}\text { Evaluation grade of } \\
\text { each parameters }\end{array}$ & I & II & III & IV & V \\
\hline $\begin{array}{c}\text { Subordinate scores of } \\
\text { each index }\end{array}$ & 1 & 3 & 5 & 7 & 9 \\
\hline $\mathrm{s}=\sum_{i=1}^{m} b_{i} \sum_{j=1}^{n}\left(c_{i j} \times k_{i j}\right)$
\end{tabular}

where: the 's' is the composite score of evaluation of canal frost heave; $b_{i}$ is the weight of the $\mathrm{i}$-th characteristic of the criteria layer; $c_{i j}$ is the index weight of the $\mathrm{j}$-th index; $k_{i j}$ is the subordinate value of the j-th selected in the i-th quasi-measure layer; $\mathrm{m}=1,2 ; \mathrm{n}=1,2,3,4,5$.

\subsection{Evaluation of the level of frost heaving}

According to the formula (1), the composite score of evaluation of canal frost heave is calculated and graded according to Table 9. The level of frost heaving increases gradually from grade $\mathrm{I}$ to grade $\mathrm{V}$.

Table 9 Classification standard of frost heaving

\begin{tabular}{|c|c|c|c|c|c|}
\hline $\begin{array}{c}\text { Comprehensive } \\
\text { evaluation grade of } \\
\text { frost heave of large } \\
\text { canal }\end{array}$ & I & II & III & IV & V \\
\hline Composite score & $<2$ & $2 \sim 4$ & $4 \sim 6$ & $6 \sim 8$ & $\geqslant 8$ \\
\hline
\end{tabular}

\subsection{Engineering application}

According to the field observation data of the large canal, the canal section with pile number $47 \mathrm{~km}$ on the shady slope is selected for evaluation. The water content before freezing is $14.8 \%$, the plastic limit water content is $17.33 \%$, the groundwater level is close to the bottom of the canal, the subordinate score of water content is 3 ; the compaction coefficient is 0.96 , the subordinate score of compaction coefficient is 5 ; the $<0.075 \mathrm{~mm}$ particle content is more than $60 \%$, the subordinate score is 1 ; the subordinate score of cumulative negative surface gas temperature is 7 ; the subordinate score of the direction of canal slope is 9 . According to this, the composite score of 
frost heaving is 2.1 and the frost heave comprehensive evaluation grade is grade II.

\section{Conclusion}

(1). The establishment of frost heave evaluation index system provides convenience for the determination of frost heave level of canal foundation soil in large canals, and the frost heave level of canal foundation can be judged only by the easily observed and obtained index data.

(2). The evaluation index system of frost heaving situation of canal foundation soil in the cold area is established by considering the influence factors of canal frost heaving, is suitable for the grade evaluation of large dam embankment foundation frost heave in a cold area, which makes the prevention of canal frost damage more targeted.

\section{References}

1. A. Y. Li, F. J. Niu, H. Zheng, S. Akagawa, Z. J. Lin, J. Luo, Cold Reg. Sci. Tech. J. 137, 68-74 (2017)

2. G. Q. Zhou, Y. K. Ji, M. Hall, Matthew, B ENG GEOL ENVIRON. J. 78, 3671-3683 (2019)

3. W. She, X. Y. Cao, G. T, Zhao, D. G. Cai, J. Y. Jiang, X. Y. Hu, Cold Reg. Sci. Tech. J. 148, 148-158 (2018)

4. G. H. Go, J. Lee, Jangguen,H. S. Shin, B. H. Ryu, H. W. Jin, D. W. Kim, INT J HEAT MASS TRAN. J. 130, 960-967 (2019)

5. X. Tan, M. S. Wu, J. S. Huang, J. W. Wu, J. J. Chen, Cold Reg. Sci. Tech. J. 173, (2020) 